W) $34 \mathrm{~m}$

No. C. 73.1

Cop.z

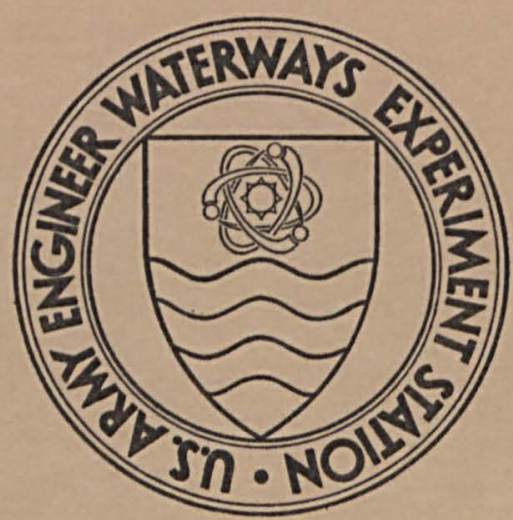

MISCELLANEOUS PAPER C-73-I

\title{
FAST SETTING CEMENT LITERATURE SURVEY
}

by

C. F. Derrington
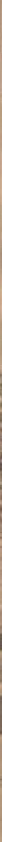

January 1973

Conducted by U. S. Army Engineer Waterways Experiment Station

Concrete Laboratory

Vicksburg, Mississippi 


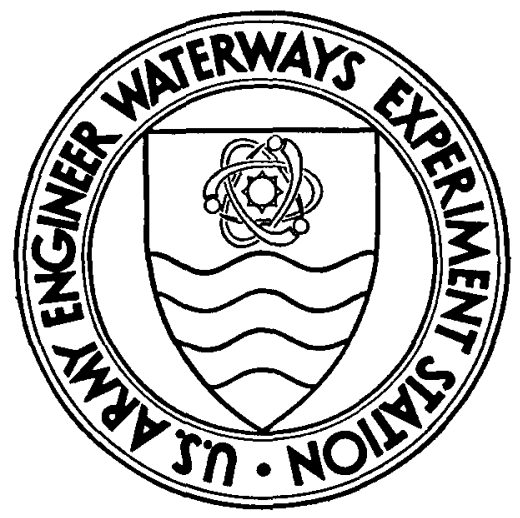

MISCELLANEOUS PAPER C-73-I

\section{FAST SETTING CEMENT LITERATURE SURVEY}

by

C. F. Derrington

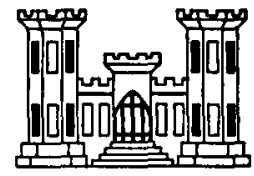

January 1973

Conducted by U. S. Army Engineer Waterways Experiment Station Concrete Laboratory Vicksburg, Mississippi 
il: $:$ mo

72.8.

- Oafin

THE CONTENTS OF THIS REPORT ARE NOT TO BE USED FOR ADVERIISING, PUBLICATION, OR PROMOTIONAL PURPOSES. CITATION OF TRADE INAMES DOES NOT CONSTITUTE AN OFFICIAT ENTDORSEMENT OR.APPROVAL OF THE USE OF SUCH COMMERCIAL PRODUCIS. 


\section{Foreword}

The literature survey included herein was conducted at the U. S. Army Fngineer Waterways Experiment Station (WES) for The Dow Chemical Company, Product Department Iaboratories, Midland, Michigan, at the request of Mr. G. M. Hart in letter of 13 May 1970, subject: Literature Survey Re Air Mobility Fast Setting Cement. - Contract No. DACA-39-70-C0022. WES personnel had previously discussed the survey with Dow representatives Messrs. R. D. Eash and G. F. Allen during their visit to WES on 5 May 1970.

Ms. Clara F. Derrington, Research Chemist, Concrete Laboratory, WES, made the survey, which is limited to a review of literature pertaining to materials. Information concerning structural requirements can probably best be obtained from other sources. The survey was made under the general supervision of Mr. Bryant Mather, Chief, Concrete Laboratory, and Director, Concrete Technology Information Analysis Center (CTIAC).

This survey is CTIAC Report 1. The cost of reproduction of it was defrayed by TISA Project 02/07.

Director of WES during preparation and publication of this survey was COL Ernest D. Peixotto, CE. Technical Director was Mr. F. R. Brown. 
Contents

$\underline{\text { Page }}$

Foreword . . . . . . . . . . . . . . . . . v

Conversion Factors, British to Metric Units of Measurement . . . ix

Summary . . . . . . . . . . . . . . . . . . xi

Introduction .................. 1

Summary . . . . . . . . . . . . . . . . . I 1

Annex A - Calcium sulfate type materials . . . . . . . . I I

Annex B - High alumina cements . . . . . . . . . . . 4

Annex C - Very fine cements . . . . . . . . . . 7

Annex D - Silico-Phosphate cements . . . . . . . . 8

Annex E-Admixtures - Organic . . . . . . . . . . 9

Annex F-Accelerators - Inorganic . . . . . . . . 9

Amex G - Miscellaneous . . . . . . . . . . . 10

Annex H - General Information . . . . . . . . . II

References . . . . . . . . . . . . . . 13 
Conversion Factors, British to Metric Units of Measurement

British units of measurement used in this report can be converted to metric units as follows:

Multiply

inches

square yards

gallons (U. S.)

pounds

pounds per square inch

Fahrenheit degrees

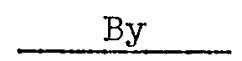

2.54

0.836127

3.78541 .2

$0.45359237 \quad$ kilograms

0.00689476

5/9
To Obtain

centimeters

square meters

cubic decimeters

megapascal $\left(=\mathrm{Mv} / \mathrm{m}^{2}\right.$ )

Celsius or Kelvin degrees*

* To obtain Celsius (C) temperature readings from Fahrenheit (F) readings, use the following formula: $C=(5 / 9)(F-32)$. To obtain Kelvin ( $K)$ readings, use: $K=(5 / 9)(F-32)+273.15$. 


\section{Summary}

Several materials are purported to be fast setting and capable of supporting loads in a relatively short time after casting. These materials are generally mixtures of several components. Some of the materials require only the addition of water prior to mixing, while some are admixtures or accelerators that are added in varying amounts to a specified cement at the time of mixing.

Literature pertaining to fast setting materials was surveyed. Copies of all available pertinent information were arranged in eight annexes. The information was classified as follows: calcium sulfates; high alumina cements; very fine cements; silico-phosphate cements; accelerators, organic; accelerators, inorganic; miscellaneous; and general. The contents of each annex are summarized herein. A list of the literature examined is also included. 


\section{EAST SETTING CENENT}

\section{Literature Survey}

\section{Introduction}

1. There are several materials that are purported to be fast setting and capable of supporting loads in a relatively short time after casting. These materials are generally mixtures of several components. Some of the materials require only the addition of water prior to mixing, while some are admixiures or accelerators that are added in varying amounts to a specified cement at the time of mixing.

2. Copies of all available pertinent information were arranged in Annexes A through $\mathrm{H}$ as shown below. Copies of the entire reports were included in some instances, abstracts in others. The literature examined is listed at the end of this report. The information examined is classified as follows:

Annex

Type Material

Annex Type Material

A Calcium sulfates

B High alumina cements

C Very fine cements

D Silico-phosphate cements

E Accelerators - organic

$F \quad$ Accelerators - inorganic

G Miscellaneous

$\mathrm{H} \quad$ General information

The contents of each annex are summarized in the following paragraphs.

\section{Summary}

3. Annex A - Calcium sulfate type materials.

a. Fast-Fix. The Western Co. has developed materials designated as Fast-Fix with rapid setting and high strength properties. Published data show 
that mortars made with Fast-Fix have flexural strengths of 546 psi*and conpressive strengths of 2318 psi at $30 \mathrm{~min}$, while concrete made with Fast-Fix has flexural strengths of 400 psi and compressive strengths of 1800 psi.. There are several Fast-Fix materials with various designations as Fast-Fix 1, Fast-Fix 2, etc. The name Fast-Fix denotes a combination of hemihydrate alpha type gypsum, portland cement, and a dispersing agent. The Portland cement varies from 5 to 20 percent in these materials.

Nosseir and Griffin investigated mix designs for Fast-Fix 1 and Fast-Fix C-1 concrete, and the results are found in TR 613 and TR 651 . Fast-Fix C-1 cement contained 20 percent Portland cement, while Fast-Fix 1 contained only 5 percent Portland cement. Fast-Fix 1 concrete apparently showed maximum strength at 1 hour, while Fast-Fix C-1 concrete continued to gain strength with age. The data indicate that for concretes with an age of 1 hour, compressive strengths up to 3300 psi can be achieved with proper selection of constituents. Decreasing the water-cement ratio increases the compressive strength and decreases the setting time, but generally the Fast-Fix C-1 cement concrete requires longer setting time than Fast-Fix 1. Fast-Fix C-1 concrete is more resistant to erosion by flowing water than Fast-Fix 1 concrete. Air-dried Fast-Fix C-I cement concrete gains more strength at age of 28 days than when fog-cured.

In another investigation, Setser et al (Vol I: "Rapid Repair of Bomb-Damaged Runways") selected and evaluated several resin formulations and 250 fast-setting cement formulations in an effort to find the most promising materials that could meet the following specification: (1) support a 29,000-1b rolling wheel load within 30 min after placement in a metric units is presented on page ix. 
boub-crater repair area, within an ambient temperature range of -5 to

$+110 \mathrm{~F},(2)$ adapt to rapid and continuous mixing and placement and (3) be self-leveling. Four materlals manufactured by U. S. Gypsum that proved most adaptable to rapid-repair techniques are, in increasing order of strength and cost:
(1). IP Cement (Fast-Fix.2)
(2) Hydroca1. White (Fast,-Fix 3)
(3) U1traca1 30
(4) Hydrostone (Fast-Fix 1)

Fast-Fix 1 consisting of 95 percent Hydrostone, 5 percent Portland cement, and 0.5 percent $\mathrm{TF}-4$ was chosen over all the other materials because of its high strength, hard wearing surface, and general slurry characteristics such as set time, viscosity, and adaptability to fillers. This formulation provides a 30 -min compressive strength of $3500^{\circ}$ psi and flexural strength of $600 \mathrm{psi}$. Among other materials tested that did not meet the requirements were Portland cęment, Lumnite cement, Por-rock, Mirament, Speed Crete, Floc-roc, Sika accelerators, Darex, Dehydratine 80, and sodiụm silicate.

Based on the findings reported in Vol I above, Pruitt et al. in Vo1 II, "Rapid Repair of Bomb-Damaged Runways," describes additional phys1cal properties of Fast-Fix 1,2, and 3. Each contains $95: 5$ weight ratios of $\mathrm{CaSO}_{4} \cdot \frac{1}{2} \mathrm{H}_{2} \mathrm{O}$ and Portland cement, plus 0.5 percent $\mathrm{TE}-4$. The only differences in the cements are in the processing procedures used on the hemihydrate. The report covers the design, fabrication, and testing of equipment to disperse Fast-Fix at rates up to $1000 \mathrm{gpm}$, and the demonstration of the 
overall material-equipment procedure performed at Eglin Air Force Base. The demonstration showed the excellent capability for rapid repair of a bomb crater, but there was an apparent need for improved equipment in '. order to accomplish the repair more efficiently.

b. U.S.'Gypsum Co.materials. Hydrostone, Hydrocal, and U1tracal are recommended for high early strength. Data sheets from U. S. Gypsum show Hydrostone to have an 11,000-psi compressive strength in the dry state and to set up in 20 to $25 \mathrm{~min}$.

Compressive strengths of grout mixtures containing Hydrostone, cement, and water: and made at the Concrete Division varied from 600 to $1400 \mathrm{psi}$ at 16 hours, depending upon the mix. The highest compressive strengths obtained using Type III cement and Plaster of paris (hemihydrate) - was 1742 psi at 1 day. A strength of 6775 psi was found for a mixture of Hydrostone and water at 24 hours when cured at $100 \mathrm{~F}$. Strength tests were not determined at earlier ages.

c. Others. Laboratory tests showed that a grouting mixture containing F-181-R DAKORAN allowed a working time of 10 min with compressive strengths at $30 \mathrm{~min}$ and 1 hour of 1810 and 3250, respectively.

It is evident by the data inclosed that the addition of $\mathrm{CaSO}_{4}$ type materials does produce early set times and high strengths. It is reported, also, that the addition of 1.5 percent $\mathrm{CaCl}_{2}$ to clinkers containIng more than normal amounts of hemihydrate increases the early strengths.

4. Annex B - High alumina cements.

a. High alumina cements have been proposed and successfully used as quick setting early strength materials. Experience and investigations 
- have shown that high alumina cements perform particularly well where the ambient temperatures do not exceed $25 \mathrm{C}$. When high alumina cement mortar or concrete is exposed to warm, moist conditions, there is a significant reduction in strength. The cause of the loss of strength is attributed to the conversion of hexagonal aluminates to the more chemically stable cubical aluminates. The water-cement ratio of the mix greatly influences this conversion.

b. Taylor reports that the setting times of high alumina cements are from 5 to $30 \mathrm{~min}$ and that useful strengths may be obtained after 15 to $60 \mathrm{~min}$. The setting time is maximum at $30 \mathrm{c}$. Above $30 \mathrm{c}$ the setting time is reduced as the temperature rises. High alumina cements are resistant to acid solutions with a minimum $\mathrm{pH}$ of 4.0 , waters containing $\mathrm{CO}_{2}$, and sulphate solutions.

c. Booth and Whitehurst claim that the compressive strengths of aluminous slag cements may be improved by a factor of 2 to 15 by the addition of 2.5-4.0 percent fluoride and other additives such as sugar, sodium metaphosphate, etc.

d. Abstracts of work done in Russia indicate that changes in. compressive strength of alumina cements with curing depend upon kinetics of phase transformations and are dependent upon temperature and hardoning conditions. Higher initial strengths were also reported for aluminum cements containing a greater than normal percentage of $\mathrm{SO}_{3}$.

e. Wilson and Wood (France) report that setting time of alumina cements obtained from phosphorus furnace slags may be increased by treatIng the cement with $\mathrm{CO}_{2}$. 
f. Robson investigated mixtures of Portland cement and high alumina cements and noted that setting time of the mixtures is affected by the method in which both cements are mixed. Addition of Portland cement to the alumina cement causes initial stiffening but relatively slow final setting and hardening; addition of alumina cement to Portland causes quick set. Mortars made using 100 percent Lumnite cement showed compressive strengths of 6380 psi at 1 day. High temperature curing produces lower strengths of high alumina cements.

g. Approximately $2000 \mathrm{sq}$ yd of concrete were replaced at aircraft runways at Yokota Air Base, Japan. Requirements for the job vere that the mixtures used for repairs should have an average flexural strength of 700 psi at 5 to 6 hours age and that 12 hours was the maximum period - of disruption that could be allowed. Asphaltic concrete was first attempted but was unsuccessful. Successful repairs were made that met the job criteria by the use of an aluminous cement produced by Asahi Glass Co., Ltd. It was recommended as a result of this job that, for future jobs, pouring should be confined to the colder months, that direct sunlight should be avoided, and that $300 \mathrm{sq}$ yd should be the maximum area which . can be replaced satisfactorily by a single paving machine.

h. Lancaster describes the thin patching of 22 spalled areas of a road at Longton, Lancashire. The repairs were made with various mortar mixes. Those mixes showing the fastest setting times were mixtures of 80 percent high alumina and 20 percent Portland cenent. These mixtures per formed well when trafficked four or five hours after laying, but it was noted that the properties of high alunina Portland cements may vary with different batches of cement. No strength data were available in this repor 
1. Unpublished laboratory test data obtained by the Concrete Division show average 1 day compressive strengths of mortar cubes made with Ciment Fondu to be approximately 7400 psi when stored at $73^{\circ} \mathrm{F}$, $7100 \mathrm{psi}$ at $60^{\circ} \mathrm{F}$, and $6300 \mathrm{psi}$ at $100^{\circ} \mathrm{F}$. A grouting mixture of ciment Fondu and water evinced compressive strengths of approximate1y $7000 \mathrm{psi}$ at 18 hours, while a grout mixture containing Lumnite cement, limestone sand, water, and plastiment showed a compressive strength of approximately 6700 psi at 1 day.

\section{Annex C - Very fine cements.}

a. The fineness of portland cement is a significant factor affecting the rate of hardening and early strength development. Brunauer et al showed that (1) clinker can be ground to desired fineness by using a varicty of grinding aids, (2) proper kinds of surface-active additives can provide excellent workability, and (3) much greater strengths than normal of hardened Portland cement pastes can be obtained. Data in the report show that by increasing the fineness to a specific surface of approximately $8000 \mathrm{~cm}^{2} / \mathrm{g}$ and by using the proper grinding aid and lignosulfonate, compressive strengths of 11,000 to 14,000 psi could be obtained at 1 day. Type I cement gives earlier strength development than Type II. Compressive strength of 3000 psi at 9 hours was obtained for a Type I cement, with 0.5 percent $\operatorname{TNN}$ as grinding aid and additional $\mathrm{K}_{2} \mathrm{CO}_{3}$ and lignosulfonate.

b. Bennett and Collings investigated high early strength concrete using a very fine Portland cement. A special cement with a specific surface of $7420 \mathrm{~cm}^{2} / \mathrm{g}$ was compared with a Portland cement of $2770 \mathrm{~cm}^{2} / \mathrm{g}$, a rapid hardening Portland cement of $4900 \mathrm{~cm}^{2} / \mathrm{g}$, the same rapid hardening cement 
plus 2 percent $\mathrm{CaCl}_{2}$, and a high alumina cement of $3610 \mathrm{~cm} 2 / \mathrm{g}$. Most tests Involved an agg-cement ratio of $3: 1$, so that low water-cement ratios could be used. Compressive strengths at 8 hours of 4-in. cubes were highest (9650 psi) for the high alumina cenent and nest highest (3350 psi) for the very fine Portland cement. Strengths at less than 8 hours were not reported.

c. Abstracts from foreign journals also indicate that particle size distribution and very fine cements will cause an early gain in strengt of cement mortars and concrete. The high initial strength is assisted by the $0-3 \mu$ fraction.

d. Although none of the values reported in the articles above showed strength data at 1 hour, it is evident that the compressive strength would be less than $3000 \mathrm{psi}$. However, the data do suggest that very fine Portland cement with additional admixtures or accelerators such as $\mathrm{CaCl}_{2}$, $\mathrm{CaSO}_{4}$, etc., may be altered to produce even higher strengths at 1 to 2 hour 6. Annex D - Silico-Phosphate cements.

a. We1ls in 1968 reported on a limited investigation of inorganic materials that would set at low temperature and which would have compressive strengths of about $10,000 \mathrm{psi}$. The cement with the greatest potential was a silicate cement composed of alumina powder, silica powder, phosphoric acid, and water. No early $(<1 d)$ strengths were reported, but compressive strengths at 1 week and 1 month showed about a 50 percent improvement over Portland cement products. It was concluded from this study that the pursui of the silicate cement should be halted due primarily to the excessive cost for large quantities. 
b. Semler investigated and evaluated 650 silico-phosphate cements and found that 10 of these showed promise for application in highway patchIng on the basis of high compressive strengths, rapid setting times (less than $10 \mathrm{~min}$ ), and low solubility. Mixtures of 90 percent wollastonite $\left(\mathrm{CaSiO}_{3}\right)$ and 10 percent blast furnace slag showed 1 day compressive strengths of greater than 10,000 psi with a set time of 5 minutes. Set time could be varied somewhat, depending upon length of mixing. The cost of the mixtures in this investigation were reported to be competitive with other quick setting or regulated setting commercial products, while offering improved properties.

7. Annex E-Admixtures - Organic. High strength concrete may be obtained by the addition of some organic constituents. Mixtures of resorcinol and formaldehyde added to Portland cement and sand are reported to cause concrete to set after $15 \mathrm{~min}$, and the tensile and compressive strengths were doubled over mix without organics after 1 week curing. Concrete made with calcium aluminate cement, aggregate, resorcinol, paraformaldehyde, and water set up in $90 \mathrm{~min}$ and had compressive strengths of 1850 psi after 4 hours.

\section{Annex F-Accelerators - Inorganic.}

a. Sika Chemical Co. produces several accelerators purported to be useful for rapid strength gain when incorporated in cement mixes. These materials are designated as follows:

Sigunit - Accelerator for shotcrete.

Sika No. 2 - Quick set for high pressure leaks.

Sika Plug - Quick setting for sealing leaks in floors, sidewalks, etc.

Sika No. 3 - For rapid hardening of mortar for sealing joints.

Sika No. 4 - For fast setting in pressure grouting.

Sigunit is composed primarily of $\mathrm{Na}_{2} \mathrm{CO}_{3}$ and silica gel. 
b. Mortar cubes using Sigunit and $\mathrm{Na}_{2} \mathrm{CO}_{3}$ were made in the $1 \mathrm{ab}$ oratory of the Concrete Division. The cubes set up in a few minutes but no early strengths were obtained.

c. Increased early strength of concrete can be obtained with the addition of $\mathrm{CaCl}_{2}$. An addition of 2 percent $\mathrm{CaCl}_{2}$ to a Type III cement requires approximately 14 hours to attain strengths of 2000 psi.

d. A combination of $\mathrm{KOH}$ and $\mathrm{CaCl}_{2}$ is purported, also, to improve initial strength.

9. Annex G-Miscellaneous.

a. The Portland Cement Association reports in a brochure that Regulated-Set is a modified portland cement that can be made to set up from 1 to $30 \mathrm{~min}$. Mortars $(1: 2)$ and $\mathrm{c}-109$ mortars are purported to show - about 1950- and 950-psi compressive strengths at 1 hour, respectively. b. Huron Cement Co., in an information bulletin dated December 1969, stated that set Regulated cement was in the development stage, but suggested mixes of 88 percent special clinker, 10 percent anhydrous calcium sulfate, and 2 percent hemihydrate calcium sulfate for early set and high strength material. Mortars made at the Concrete Division with varying amounts of these additives and varying amounts of water showed compressive strengths at 1 hour of 250 to 920 psi.

c. Darcrete is a fast-setting cement that is purported to take an initial set in 10 to $15 \mathrm{~min}$ and to have a minimum compressive strength of 2200 psi in 24 hours.

d. Mari-crete is a commerical product that claims high strength and may be used for patching and repairing. Compressive strengths at 24 ho 
are about $3000 \mathrm{psi}$, and tensile strengths vary from approximately 150 to 350 psi, depending upon the curing conditions.

e. Quick-Wotaito is a liquid accelerator for cement that sets up from $30 \mathrm{sec}$ to 1 hour. The available data sheets do not state the strength of mixes made with Quick-Wotaito.

f. There are other means that may produce high strength concrete. They include addition of iron, as aggregate, physical treatment of clinker, addition of highly reactive $\mathrm{SiO}_{2}$ or $\mathrm{CaO}$, and mixtures of iron powder and aqueous solution of dichromate or permanganate and a chloride.

g. A project plan entitled "Cementitious Materials for Ship Salvage," is. included in this Annex. The project involves an investigation of high early strength Portland cement pastes made with seawater and various admixtures. The results of the investigation may prove helpful in the search for a fast-setting cement.

10. Annex H - General information. A bibliography and several articles or abstracts on high strength concretes are included in this Annex. These articles do not pertain necessarily to high early strength concrete, but the information in the articles and the discussion of factors that contribute to high strength concrete should be beneficial in consideration of the development of a quick set high early strength material. Some of the factors, in addition to the ones presented in the other Annexes, that should be considered or investigated to obtain high early strength are as follows: compression, high. frequency vibration, improvement of bond by use of cementitious aggregates, low water-cement ratios, curing conditions, improved grading of particle sizes, type of mixing, and sequence of addition 
- of materials during mixing. A combination of factors such as the addition of accelerators and/or admixtures (as discussed in this report) to improved Portland cement (fineness, special clinkers, etc.) plus improved. methods of mixing and compaction should result in a concrete having quick set properties and high strengths. 
NOTE: Letters in parentheses indicate Annex in which reference is found. Allied Chemical Co., "Better Concrete with Calcium Chloride," Bulletin, no date. (F)

Anon., "Fast Concrete Speeds Repair Work," Mid-West Contractor, January 22, 1969, pp 14 and 15.(A)

Anon., "High Strength Concrete," Am. Con. Inst., Proceedings, vol 64, No. 7 , July 1967, pg 426.(H)

Anon., "High Alumina Cement," (Japanese), abstract, Am. Con. Inst., Proceedings, vol 66, No. 9, September 1969, pg 777.(B)

Anon., "Methods of Achieving High Strength Concrete," Am. Con. Inst., Proceedings, vol 64, No. 1, January 1967, pp 45-48.(H)

Anon., "Tentative Interim Report on High Strength Concrete," Am. Con.

Inst., Proceedings, vol 64, No. 9, September 1967, pp 556 and 557.(H)

Atlas Minerals and Chemicals Division, ESB Inc., Mertztown, Pa., "Exide Mari-Crete," Bulletin, 1968.(G)

Bailey, W., "Runway Repairs Using Aluminas Cement Concrete," Yokota Air - Base, Japan. (B)

Bela Beke, "Grinding Methods for the Production of Various Cements," Chemical Abstracts, vo1 56, No. 9, 1962, 9718i.(C)

Bendinelli, R., Data sheets of compressive strengths of hydrostone mixes, $1958,1970$. (A)

Bendinelli, R., Data sheets of mix design and compressive strengths using F-181-R DAKORAN, January 1969. (A)

Bendinelli, R., Data sheets of compressive strengths of mixes of quicksetting high strength materials, no date.(A)

Bendinelli, R., Data sheets on high strength grouts, Lumnite, Climent Fondu.(B)

Bennett, E. W., and Collings, B. C., "High Early Strength by Means of Very Fine Portland Cement," The Institution of Civil Engineers, Proceedings, vol 43, July 1969, pp 443-552.(C)

Booth, C. F., and Whitehurst, B. M., "High Compressive Strength Aluminous Cement slag," Chemical Abstracts, vol 65, No. 7, 1966,10318 f.(B)

Brunauer, S., Mikhail, R., and Yudenfreund, M., "Hardened Cement Pastes of Low Porosity Exploratory Studies," Research Report 68-9, June 1968, Bureau of Physical Research, New York State Department of Transportation. (C) 
Bussone, P., Data sheet dated 11 May 1970 on Sigunit and sodium carbonate mixes. (F)

Bussone, P., Data sheets dated 11 May 1970 entitled'Early S trengthRegulated Set Cement."(G)

Butt, Yu M., and Timashev, V. V., "Technological and Physical-Chemical Characteristics of the Manufacture of Rapid and High-Strength Cements," Chemical Abstracts, vol 70, No. $18,1969,80593$ d. (G)

Cannon, E. A., Letter dated 7 January 1970, "Repairs to Airfield Pavements.

Collins, J. D., and Shriver, E. L., "High-Strength Concrete Compositions," Chemical Abstracts, vol 64, No. 4, 1966, 4779b.(E)

Collins, J. D., and Corwin, J. F., "High-Strength Concrete," Chemical Abstracts, vol 70, No. 12, 1969, 50222q. (E)

Culpepper, M., Memorandum dated 28 August 1967.(A)

Dacar Chemical Co., Pittsburgh, Pa., Bulletin, "Darcrete Fast Setting Cement Datt, J., "High Alumina Cement," The Indian Concrete Journa1, vo1 42, No. 3 , March 1968, pp 89 and $90 .(B)$

"Duriez, Marius J. J., "Concrete Having Improved Initial and Final Strength," Chemical Abstracts, vol 59, No. 5, 1963, 4894e.(F)

Fateeva, N. I., Tagiltsev, A. Z., and Bebeshko, V. I., "The Character of the Curves Showing the Relation Between the Strength of the Hydrated Cement and Its Content of Hydrated Calcium Sulfate," Chemical Abstracts, vol 59, No. $12,1963,13678$ e.(A)

Gado, Eugene, "Additive for High-Compressive-Strength Concrete," Chemical Abstracts; vol 69, No: $10,1968,38516 \mathrm{k}$. (G)

Griffin, D. F., "Mix Designs for Fast-Fix C-1 Cement Concrete," Technical Report R651, November 1969, Naval Civil Engineering Laboratory, Port Hueneme California.(A)

Hughes, B. P, and Bahramian, "Some Factors Affecting the Compressive Streng of Concrete," Am. Con. Inst., proceedings, vol 65, No. 11, November 1968, pq

Isakovski, Slobodan, "Effect of Fineness of Grinding and of Fine Particles of Elementary Iron on the Mechanical Strengths of Portland Cement," Chemical Abstracts, vol 57, No. 10, 1962, 12109e.(C)

Kelly, T. M., Mielenz, R. C., and Peppler, R. B., "Glucosaccharides for Strengthening Cement," Chemical Abstracts, vol 65, No. 1, 1966, 474h. (E) 
Kogyo, I. P., "Product for Increasing the Strength of Cement," Chemical Abstracts, vol 63, No. 3, 1965, 2731h. (G)

Kuerner, R., "Quick-Setting Cements," Chemical Abstracts, vol 68, No. 8, $1968,32922 x$. (B)

Kutateladze, K. S., Gabadadze, T. G., and Suladze, I. S., "Alunite Additions Decrease the Setting Times and Increased the Strength of Concrete," Chemical Abstracts; vol 72 , No. $8,1970,35369 \mathrm{r} .(\mathrm{B})$

Lancaster, I. E.; Road Research Laboratory Report IR26, "Ear1y Trafficking of Thin Concrete Patches," Road Research Laboratory, Crowthorne, Berkshire, 1969. (B)

Mather, Katharine, "High-Strength, High-Density Concrete," Chemica1 Abstracts, vol 63, No. 11, 1965, 14526h.(G)

Miller, W., Data sheet on results of test on high alumina cement dated 16 Apri1 $1970 .(B)$

Nasser, George D., "Are We Headed Toward Very High Strength Concretes," Am. Con. Inst., Proceedings, vol 65, No. 10, October 1968, pg 898.(H)

Nasser, George D., "Bibliography on High Strength Concretes," Am. Con. -Inst., proceedings, vol 64, No. 10, October 1967, pp 690-691.(H)

Nikitina, "The Effects on the Hydration of Cements of Increasing Additions of Gypsum of Different Modifications," Chemical Abstracts, vol 56, No. 4, $1962,3127 \mathrm{~g}$. (A)

Nippon Cement M. F. G. Co., Kobe, Japan, "Quick-Wotaito Quick-Hardening Agent for Cement," Bulletin, no date.(G).

Nosseir, S. B., and Katona, M. G., "Mix Designs for Fast-Fix 1 Concrete," Techrical Report R613; February 1969, Naval Civil Engineering Laboratory, port Hueneme, California.(A)

Nosseir, S. B., and Katona, M. G., "Structural Behavior of Reinforced Concrete Beams Wade with Fast-Fix 1 Cement," Technical Report R614, February 1969, Naval Civil Engineering Laboratory, Port Hueneme, California.(A)

Okada, Kiyoshi (Japan), "High-Strength Concrete," Chemical Abstracts, vol 71, No. 4, 1969, 15751k.(H)

Portland Cement Association, data sheets on regulated-set cement, August 1969.(C

Pruitt, G. T., Anderson, R. A. et al, "Rapid Repair of Bomb-Damaged Runways," vo1 II, Technical Report A FAPL-TR-67-165, vol II, April 1968, Air Force Aero Propulsion Laboratory, Air Force Systens Command, Wright-Fatterson Air Force Base, Ohio.(A) 
Ranco Industrial Products Corporation, Ranco Industrial Maintenance Catalog, 1968.(A)

Ritenbergs, V., Vaivads, A., and Zarina, A., "Effect of Water-Soluble Organosilicon Compounds and of Conplex Additions on the Properties of Concrete. Effect of Additions of Sodium Methylsilicate, Sodium Aluminomethylsilicate, and Calcium Chloride on Strength of Concrete," Chemical Abstracts, vol 66, No. 24, 1967, 107960c.(E)

Ritzmann, H., "Relation Between Particle Size Distribution and the Strength of Portland Cement," Chemical Abstracts, vol 70, No. 4, 1969, 14178w.(C)

Robson, T. D., "The Characteristics and Applications of Mixtures of Portland and High-Alumina Cements," Chemistry and Industry, January 5, 1952.(B)

Sanders, Charles E., "A Quick-Setting Silico-Phosphate Cement," Report No. F H-11-7321, Phase I, Monsanto Research Corp., Dayton Laboratory, Dayton, Ohio, March 1970.(D)

Setser, W. S., Pruitt, R. A. et a1, "Rapid Repair of Bomb-Damaged Runways," vol I, Technical Report AFAPI-TR-67-165, March 1968, Air Force Aero Propulsion Laboratory, Air Force Systems Command, Wright-Patterson Air Force Base, Ohio.(A).

Sheiken, A. E., and Rabinovich, F. N., "Durability of Concrete Based on Alumina Cement," Cherical Abstracts, vol 67 , No. 22; 1967, 102538g.(B)

Sheiken, A. E., and Rabinovich, F. N., "The Strength of Concrete with Alumina Cement and the Factors Controlling It," Chemical Abstracts, vol 68, No. $16,1968,71888 \mathrm{k}$. (B)

Shipilov, A. P., "Qujck-Hardening Concretes Based on Cements from the Angren and Begovat Factories," Chenical Abstracts, vol 56, No. 8, 1962,8306

Sika'Chemical Corp., Data sheets on Sigunit and other Sika quick-setting materials. (F)

Simeonov, Bozhinov, et al, "Acceleration of Hardening of Concrete with a Quick-Setting Cement," Chemical Abstracts, vol 68, No. 24, 1968, 107657a. (A)

Soko1, "Rapid Runway Repair,".Air Force Civil Engineer, vo1 11, No. 1, February 1970, pp 24 and 25 . (B)

Taylor, H. F. W., The Chemistry of Cements, vol 2, Academic Press Inc., New York, 1964, pp 17-26.(B)

The Western Co., Data sheets on Fast-Fix and Fast-Fix C-1, no date. (A)

Uchikawa, Hiroshi (Japan), "Strength of Hydrated Cements," Chemical Abstracts, vol 69, No. 6, 1968, 21697x.(H) 
United States Gypsum Co., Data sheets of physical results of U1tracal, Hydrocal and Hydrostone. General information sheets, 1965.(A)

Walley, $D_{.}$, Memorandum of meeting with representatives of The Western Co., February 20, 1969.(A)

We1ls, W. M., Memorandum, "Limited Investigation of Dental Silicate Cement," September 1968.(D)

Wilson, A., and Wood, A., "Alumina Cements," Chemical Abstracts, vo1 65, No. $3,1966,3545 f .(B)$ 
Cements

Fast setting cements

$111 K A$

LINK

B

LItiKC

W T

WT

ROLE

;

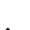

